\title{
Do students take the predictions of human capital theory into account? An analysis of motives behind further studies in higher education
}

\author{
HAJNALKA FÉNYES* (1) and MÁRTA MOHÁCSI* (1)
}

Department of Sociology and Social Policy, University of Debrecen, Egyetem tér 1, Debrecen, 4032, Hungary

\section{RESEARCH PAPER}

Published online: March 30, 2020

(c) The Author(s) 2020

\begin{abstract}
In this paper, we seek to answer the research question as to whether students take into account the predictions of human capital theory (namely the higher wages associated with further studies) in their decision to participate in higher education. Our alternative research question is whether students can be described by Bourdieu's theory on capital conversion, that is, whether they aim to accumulate cultural and social capital during their studies, which can also be profitable for them in the future. Our research method is quantitative: we use cluster analysis to examine the motives behind further studies and employ cross tabulation and variance analysis to reveal the relationship between clusters and social background variables. We find that the wage premium associated with further studies is not the most important motive among students; it holds only minor importance even for those from a disadvantaged social background. The results suggest that students in secondary schools, especially talented but underprivileged ones, should be motivated to enter higher education by informing them about the potential wage premium they can attain if they study further. Importantly, we also find that underprivileged students may be unaware of the fact that higher education is an efficient mechanism to accumulate social and cultural capital, which then can be converted into economic capital.
\end{abstract}

\section{KEYWORDS}

higher education students, motives behind further studies, quantitative analysis, human capital theory

\footnotetext{
*Corresponding authors. E-mail: fenyes.zsuzsanna@arts.unideb.hu (H. Fényes); mohacsi.marta@arts.unideb.hu (M. Mohácsi)
} 


\section{INTRODUCTION}

In this study, we analyse the motivation to pursue higher education studies and the demographic and social background variables which affect it, based on a database of student surveys. Our research question asks as to what extent the decision to undertake higher education studies is influenced by subsequent higher wages and better employment opportunities associated with higher education; in other words, to what extent this decision can be regarded as human capital investment. Human capital theory predicts that students could be primarily motivated by financial return in the future, although the importance of social and cultural capital acquired during higher education studies should not be understated, either. Students may convert the social and cultural capital they have accumulated into economic capital, that is to say, even these capital forms could yield a financial return. We also highlight that Engler (2012, 2013), in her analysis of mothers' choices to participate in higher education, explores so-called fields of return, where further studies may have multiple goals besides increasing economic capital. For instance, the intellectual capital gained by females in higher education offers a return in their family relationships (with their children and spouse), and social capital acquired during higher education studies could also yield a return in the private sphere.

\section{THEORETICAL BACKGROUND AND HYPOTHESES}

According to human capital theory, the return to investing in higher education (including the associated costs and the things which one gives up for studying) materialises in subsequent higher wages (Becker, 1994; Mincer, 1958; Schultz, 1971).

In Hungary, the expansion of higher education might have a significant impact on the return to investing in higher education. Galasi $(2005,2007)$ argues that a higher labour market supply of people with a tertiary degree, alongside fixed demand, could cause a decline in the wage premium of higher education relative to secondary education. It is also likely that recent graduates might earn significantly less than older individuals who graduated earlier.

Nevertheless, various studies about Hungary reveal that the wage premium of higher education does exist, despite the expansion of higher education (Csillag et al. 2018). This is because both the supply of graduates and the demand for them increased simultaneously, which is why the wage premium has not diminished substantially, and recent graduates do not earn much less than their older counterparts (Galasi, 2005, 2007; Kertesi \& Köllö, 2007). Whereas human capital theory focuses primarily on the supply side, the evolution and adjustment of demand should also be taken into account when calculating the return on investment. In Hungary, the rise in the labour force of tertiary graduates has been absorbed by the labour market.

In our research question, we ask as to how much motivation is derived, with respect to higher education, from financial return, ease of finding a job and having a prestigious profession (we can only investigate whether students take these aspects into account in their decision to enter higher education; we are not able to assess the actual return). In this paper, we also examine the social background variables which influence the motives (motivational types) behind pursuing higher education studies. 
In this study, we also consider Bourdieu's (1986) theory on capital forms, additionally to human capital theory. The definition of capital originates from economics, according to which the acquisition of capital goods is accompanied by a temporary drop in consumption (as one must invest in having capital goods), and possessing these goods leads to a subsequent rise in productivity. One can differentiate between two forms of capital: financial and physical capital (buildings, machines, equipment, etc.) (Samuelson \& Nordhaus, 2010). Besides economic capital, Bourdieu distinguishes between cultural and social capital and describes the convertibility of capital forms.

In his investigation on the French education system, Bourdieu remarks that cultural resources may function as capital because possessing these goods also elevates subsequent productivity. Acquiring cultural capital also constitutes an investment, which occurs partly through participation in education and partly during the socialisation process in the family. This investment might yield a profit, that is, cultural capital may subsequently be converted into economic capital. Cultural capital could take the form of internalised or incorporated capital (e.g. persistent abilities), objectivated cultural capital (paintings, books, encyclopaedias, etc.), and institutionalised capital, such as the level of schooling and certain titles (Bourdieu, 1986).

In Bourdieu's definition, social capital is the collection of actual and potential resources which are available to an individual through mutual connections. This implies that it is not only the extent of the social network that matters, but economic, cultural, and social resources provided by one's connections also play a role. Furthermore, Bourdieu also highlights the importance of social capital which is based on group membership.

Bourdieu (1986) argues that economic capital is primarily convertible to money, while cultural and social capital may be, under certain conditions, converted into economic capital. In addition, economic capital could provide a firm basis for the other two capital forms. However, cultural and social capital may not be converted into economic capital exclusively, and economic capital in itself is insufficient for the acquisition of cultural and social capital.

Higher education could provide the opportunity for capital conversion. In particular, students might convert the social and cultural capital they acquire during their studies into economic capital by getting a better job. In her studies, Pusztai $(2014,2015,2018)$ highlights the positive impact of students' social resources both on their academic achievement and during their subsequent job search.

The novelty of this study is that we analyse the order of importance for motives behind the decision to pursue further studies, and test in this form the extent to which students consider the predictions of human capital theory. Additionally, we create groups from students by cluster analysis based on the examined 10 motivations. The analysis of motives is followed by an investigation of students' capital acquisition motivations and capital conversion possibilities, based on Bourdieu's works.

Motivations behind pursuing higher education studies have two major types: intrinsic and extrinsic motives ${ }^{1}$ (Lepper, 1988). According to Pires (2009), ${ }^{2}$ intrinsic motives include the faith

${ }^{1}$ Bocsi (2015) also distinguishes between intrinsic and extrinsic motivations, but she does so in relation to higher education students' work values, which have several similar features.

${ }^{2}$ The section of the survey in relation to motivations to pursue further studies is based on the study by Pires (2009). 
in studying, the love for learning, the reinforcement of social relationships, as well as professional considerations, which comprise career-building and skill improvement (in the study, we discuss professional motives extensively). Extrinsic motives include economic advantages, ease of employment and external pressure from the family, parents, friends or the workplace. The third motivational type is the derivative motive (when an individual studies to avoid boredom or to postpone having to work). In addition, cultural mobility may also be an important goal if the parents' social situation is considered.

In this study, we hypothesise that motivations are dependent on students' gender and social background. Thompson and Subich (2006) reveal that students from a favourable social background choose a career path in a more decisive and goal-oriented manner, while they also incorporate rational motives (which concern a better job or advancement in the future) into their decision. Furthermore, the applicant's place of residence might influence the decision about higher education studies. Since most higher education institutions operate in larger towns, students from villages or small towns face additional costs, which is why financial considerations with respect to higher education studies could be more important for them (Christofides et al. 2006). Contrary to Thompson and Subich (2006), Veroszta (2014) finds that highly educated parents' children are less motivated by the financial return to investing in tertiary education than those whose parents have a low level of cultural capital, and shows that students' financial motivations are also less pronounced when professional connections with the family are present. Based on Veroszta (2014) we suppose that students from a favourable economic and cultural background take the predictions of human capital theory into account to a lesser extent, that is, financial motivations are not as instrumental to them as they are to their underprivileged peers. We hypothesise as well, based on Fényes (2010), that males consider financial return to be more important than females.

\section{DATA AND METHODS}

The data we use is based on the IESA survey (Institutional Effect on Students' Achievement in Higher Education), realised in the framework of SZAKTÁRNET project (TÁMOP-4.1.2.B.213/1-2013-0009). The survey was conducted in 2014 in the historical Partium region by collecting 1,792 responses from bachelor's students in their second year and master's students in their first year. The region in question is the cross-border area of three countries (two counties of Eastern Hungary, the Western border region of Romania, and Zakarpattia Oblast in Ukraine). Responses were gathered with the intention of representativity with respect to discipline and faculty by surveying an entire seminar group, selected at random, at each faculty.

Our research is quantitative. The methods we implement using the SPSS software package include cross tabulation, analysis of variance and cluster analysis. The motives behind higher education studies are investigated through cluster analysis because factor analysis has not yielded meaningful results (the total variance explained by factors was considerably below $50 \%$ ). Cluster analysis has the advantage that it forms groups from people, unlike factor analysis, which does so from motivational variables, but it has the disadvantage that the connections between clusters and social background variables cannot be analysed with linear regression and only bivariate methods can be employed. 


\section{FINDINGS}

First, we analyse the order of importance for motives behind the decision to pursue further studies (Table 1).

According to Table 1, students agree that advancing their knowledge (increasing cultural capital) is the most important goal of higher education, and it is only after this that they consider easier employment opportunities and a prestigious profession (in other words, professional advancement). Large income and networking are only the fourth and fifth most important items, respectively. Following the example of friends and family, and prolonging labour market entry constitute the bottom three motives. Factors of moderate relevance include the hope of a leadership position, and following the parents' and teachers' advice in the decision about further studies.

In the following, we present four groups (clusters), which have been created from students based on the ten motives. The clusters are named the following: (1) capital increasing (economic, cultural and social), (2) capital increasing with family pressure, (3) mainly cultural capital increasing, (4) marked financial and professional orientation. The four groups each comprise 323 to 588 students (see Table 2).

With respect to the gender composition of the clusters, no significant differences can be shown; that is to say, gender does not influence the motivations behind the decision to pursue further studies. Interestingly, we find that males and females are equally likely to be motivated by financial factors, even though one could have presumed financial matters to be more important for males.

In the following, we analyse students' place of permanent residence at the age of 14 by clusters and find significant differences (Table 3 ).

Table 3 reveals that more students of urban (county seat or capital) origin have capital increasing motives, which is in accordance with expectations. Residents of small towns are also

Table 1. Order of importance for motives behind further studies (the fraction of those who marked each motive $^{\mathrm{a},)^{\mathrm{b}}}$

\begin{tabular}{lr}
\hline Advancing my knowledge & $94.3 \%$ \\
Making it easier to find a job & $83.8 \%$ \\
Having a prestigious job & $80.0 \%$ \\
Finding well-paying employment & $76.4 \%$ \\
Making a variety of connections & $67.4 \%$ \\
Following my parents' and teachers' & $44.9 \%$ \\
$\quad$ advice & $44.5 \%$ \\
Having better chances at reaching a & \\
$\quad$ leadership position & $21.6 \%$ \\
Following the example of my family & $20.6 \%$ \\
Prolonging labour market entry & $12.9 \%$ \\
Following the example of my friends &
\end{tabular}

Source: IESA 2014.

${ }^{\text {a }}$ Have the following factors played an important role in your decision to pursue further studies in higher education? (1: yes, 0 : no, multiple answers were allowed). ${ }^{\mathrm{b}}$ The percentage of master's students was $22.3 \%$ in the sample, but our questions concerned the motives behind further studies which they had after secondary school and not after their bachelor training. 
Table 2. Clusters created from motives behind further studies (cluster centres above 0.5 are marked grey) ${ }^{\mathrm{a}}$

\begin{tabular}{|c|c|c|c|c|}
\hline & $\begin{array}{l}\text { Capital } \\
\text { increasing }\end{array}$ & $\begin{array}{c}\text { Capital increasing } \\
\text { with family } \\
\text { pressure }\end{array}$ & $\begin{array}{c}\text { Mainly cultural } \\
\text { capital } \\
\text { increasing }\end{array}$ & $\begin{array}{c}\text { Marked financial } \\
\text { and professional } \\
\text { orientation }\end{array}$ \\
\hline $\begin{array}{l}\text { Finding well-paying } \\
\text { employment }\end{array}$ & 0.94 & 0.85 & 0 & 1 \\
\hline Having a prestigious job & 0.96 & 0.86 & 0.54 & 0.77 \\
\hline $\begin{array}{l}\text { Having better chances at } \\
\text { reaching a leadership } \\
\text { position }\end{array}$ & 0.97 & 0.6 & 0.07 & 0.15 \\
\hline Advancing my knowledge & 0.97 & 0.94 & 0.9 & 0.94 \\
\hline $\begin{array}{l}\text { Making it easier to find a } \\
\text { job }\end{array}$ & 0.95 & 0.91 & 0.54 & 0.86 \\
\hline $\begin{array}{l}\text { Prolonging labour market } \\
\text { entry }\end{array}$ & 0.2 & 0.39 & 0.12 & 0.15 \\
\hline $\begin{array}{l}\text { Making a variety of } \\
\text { connections }\end{array}$ & 0.9 & 0.86 & 0.54 & 0.04 \\
\hline $\begin{array}{l}\text { Following the example of } \\
\text { my family }\end{array}$ & 0.01 & 0.94 & 0.08 & 0.04 \\
\hline $\begin{array}{l}\text { Following the example of } \\
\text { my friends }\end{array}$ & 0.03 & 0.51 & 0.03 & 0.05 \\
\hline $\begin{array}{l}\text { Following my parents' and } \\
\text { teachers' advice }\end{array}$ & 0.53 & 0.91 & 0.24 & 0.19 \\
\hline$N$ & 588 & 342 & 323 & 512 \\
\hline
\end{tabular}

Source: IESA 2014.

${ }^{\mathrm{a}} \mathrm{K}$-means cluster analysis, missing data have been treated by pairwise method, number of iterations: 100 .

Table 3. Place of permanent residence at the age of 14 by clusters of motives behind further studies (\%) ${ }^{\mathrm{a}}$

\begin{tabular}{lcccc}
\hline & County seat or capital & Small town & Village & Total \\
\hline Capital increasing & $\underline{31 \%}$ & $34 \%$ & $35 \%$ & $100 \%$ \\
Capital increasing with family pressure & $26.4 \%$ & $34.9 \%$ & $38.7 \%$ & $100 \%$ \\
Mainly cultural capital increasing & $20.1 \%$ & $35 \%$ & $\underline{44.9 \%}$ & $100 \%$ \\
$\begin{array}{l}\text { Marked financial and professional } \\
\quad \text { orientation }\end{array}$ & $24.9 \%$ & $\underline{40.8 \%}$ & $34.3 \%$ & $100 \%$ \\
$N$ & 434 & 603 & 619 & 1,656 \\
\hline
\end{tabular}

Source: IESA 2014.

The chi-squared test is significant at the ${ }^{\star \star}$ level.

${ }^{a}$ Here and in the tables to follow, ${ }^{*}$ marks significance between 0.01 and 0.05 , ${ }^{* *}$ marks significance between 0.001 and 0.01 , and ${ }^{* * *}$ marks significance below 0.001 . Underlined values indicate that the cell has more cases than what is implied by random distribution, that is, the adjusted residual value is higher than 2 .

overrepresented among the financially and professionally oriented (although they are better off than rural residents but it seems that money is also more important to them). Among those who mainly wish to advance their knowledge (increase their cultural capital), there are fewer urban and more rural residents than the average. 
Table 4. Fraction of those who face regular financial difficulties in the family (\%) by clusters of motives behind further studies

\begin{tabular}{llcr}
\hline & No & Yes & Total \\
\hline Capital increasing & $90.59 \%$ & $9.41 \%$ & $100 \%$ \\
Capital increasing with family pressure & $\frac{92.9 \%}{85.05 \%}$ & $7.1 \%$ & $100 \%$ \\
$\begin{array}{l}\text { Mainly cultural capital increasing } \\
\text { Marked financial and professional } \\
\quad \text { orientation }\end{array}$ & $86.79 \%$ & $\underline{14.95 \%}$ & $100 \%$ \\
$N$ & 1,420 & $17.21 \%$ & $100 \%$ \\
\hline
\end{tabular}

Source: IESA 2014.

The chi-squared test is significant at the ${ }^{\star}$ level.

Table 5. Means of certain social background variables by clusters of motives behind further studies

\begin{tabular}{|c|c|c|c|c|c|}
\hline & & $\begin{array}{l}\text { Father's } \\
\text { years of } \\
\text { education }\end{array}$ & $\begin{array}{l}\text { Mother's } \\
\text { years of } \\
\text { education }\end{array}$ & $\begin{array}{c}\text { Objective } \\
\text { financial } \\
\text { situation index }\end{array}$ & $\begin{array}{l}\text { Subjective } \\
\text { financial } \\
\text { situation }\end{array}$ \\
\hline \multirow[t]{3}{*}{ Capital increasing } & Mean & 12.29 & 12.76 & 5.84 & 5.16 \\
\hline & $N$ & 474 & 472 & 558 & 498 \\
\hline & $\begin{array}{l}\text { Standard } \\
\text { deviation }\end{array}$ & 2.32 & 2.35 & 2.25 & 1.24 \\
\hline \multirow{3}{*}{$\begin{array}{l}\text { Capital increasing } \\
\text { with family } \\
\text { pressure }\end{array}$} & Mean & 13.38 & 13.62 & 5.80 & 5.32 \\
\hline & $N$ & 300 & 301 & 342 & 307 \\
\hline & $\begin{array}{l}\text { Standard } \\
\text { deviation }\end{array}$ & 2.61 & 2.65 & 2.30 & 1.24 \\
\hline \multirow{3}{*}{$\begin{array}{l}\text { Mainly cultural } \\
\text { capital increasing }\end{array}$} & Mean & 12.62 & 12.97 & 5.52 & 5.05 \\
\hline & $N$ & 292 & 288 & 323 & 301 \\
\hline & $\begin{array}{l}\text { Standard } \\
\text { deviation }\end{array}$ & 2.38 & 2.42 & 2.07 & 1.25 \\
\hline \multirow{3}{*}{$\begin{array}{l}\text { Marked financial } \\
\text { and professional } \\
\text { orientation }\end{array}$} & Mean & 12.59 & 12.88 & 5.65 & 4.97 \\
\hline & $N$ & 464 & 458 & 512 & 468 \\
\hline & $\begin{array}{l}\text { Standard } \\
\text { deviation }\end{array}$ & 2.32 & 2.34 & 2.15 & 1.19 \\
\hline ANOVA & & $* * *$ & $* * *$ & NS & $* *$ \\
\hline
\end{tabular}

Source: IESA 2014.

Now we examine the financial situation of students' families (the regular occurrence of financial difficulties) by clusters (Table 4).

Table 4 shows that those who wish to increase all three (economic, cultural and social) capital forms are less likely to experience financial difficulties in the family (the adjusted residual value reveals that this is primarily true for those who increase their capital under family pressure), which is a significant and expected relationship. Furthermore, we find that financial difficulties are more common in the main knowledge (cultural capital) increasing group (this is discussed in detail in the concluding section). 
Means of the father's and mother's years of education, as well as of the objective (index created based on the possession of durable consumption goods, 1-10) and subjective (1-10 ranking compared to an average family in the country) indicators of financial situation, by motives behind further studies, are presented in Table 5.

Based on Table 5, the mother's and father's years of education are the highest among those who increase their capital under family pressure, which corresponds to expectations (highly educated parents strongly encourage their children to pursue higher education studies and increase their capital).

There is also a significant difference with respect to subjective financial self-evaluation (of the family on a 1-10 scale). In the group with marked financial and professional orientation, the subjective index is the lowest, which implies that children from subjectively disadvantaged families are eager to earn much, as expected. For those in a favourable financial situation, the capital increasing motive with family pressure is more frequent.

\section{CONCLUSION}

Among the motives behind the decision to pursue higher education studies, the elevated salary associated with higher education is only the fourth in the order of importance, while professional goals are listed only in the second and third places, respectively. This strongly suggests that students take the predictions of human capital theory into account only partially. The most relevant motive behind further studies is the advancement of one's knowledge. We have created four groups based on the motives behind the decision to enter higher education. The largest group is the (economic, cultural and social) capital increasing one, followed by one with marked financial and professional orientation; the third cluster contains those who wanted to increase economic, cultural, and social capital under family pressure, while the smallest group consists of students who mainly wanted to increase their cultural capital. We have also analysed the connection between motives and social background variables.

Interestingly, we find that it is not highly educated and affluent parents' children who display mainly cultural capital increasing motivations for higher education (even though it could be a traditional attitude among intellectuals). The best economic and cultural situation can be observed among those who increase their economic, cultural, and social capital under family pressure. In accordance with expectations, marked financial and professional orientation is mostly common among students from disadvantaged families.

It is also an important and unusual finding that the main cultural capital increasing group (those who wish to enhance their knowledge) consists primarily of students from a rural background and a financially underprivileged family. Contrary to expectations, these students do not consider financial and professional (career-building) goals, which are attainable through higher education, as important. We presume that this might be explained by students' ignorance about the extent of wage premium for further studies and a tertiary degree. As a consequence, some students make their decision about further studies in a way which is not based on rational calculation; and it is precisely their disadvantaged background, namely the lack of highly educated and successful people in their environment who could serve as examples, which may bring about this situation. 
It should also be highlighted that marked financial and professional orientation is more common among urban residents than among rural natives, although the standard of living is higher in towns than in villages. According to a possible explanation, urban residents may have a better understanding of the wage premium associated with further studies and also encounter more positive examples in their environment.

Motivations do not seem to differ by gender, which partially contradicts previous findings, namely that financial considerations are usually more important for males than females.

In sum, the hypothesis we have formulated can be confirmed only partly: the decision to pursue higher education studies is motivated by financial return to a small degree; however, it cannot be ruled out that the observation is valid only ostensibly because it is the result of students' norm compliance in their responses (it is 'out of fashion' to care about money). In addition, we find that it is rather capital conversion which could be characteristic of students, since they wish to accumulate cultural and social capital during their higher education studies (this is what motivates them), which, we presume, yields a subsequent return to them financially (and possibly even in their private life).

It is also an important finding that socially disadvantaged students might not make the decision about further studies based on rational calculation, and could be unaware of the market value of a tertiary degree. This suggests that it would be worthwhile to make disadvantaged but talented students understand the importance of higher education and the associated wage premia, which, we assume, would increase the proportion of those who pursue higher education studies among them (although we know that often it is not ignorance which is the main obstacle to higher education entry but the family's unfavourable financial situation and lack of cultural capital, which is not the case for students of privileged background). Importantly, we also find that underprivileged students may be unaware of the fact that higher education is an efficient mechanism to accumulate social and cultural capital, which then can be converted into economic capital.

Our analysis is limited in that we have examined the motives to pursue further studies only in relation to demographic and social background variables, and have not investigated differences between various countries as well as across fields, faculties, and levels of education. It would be interesting to explore the motives to enter a tertiary degree programme with respect to individuals' admission ranking and, if applies, previous higher education experience. This research could be carried out in another study. Through multivariate methods, the actual return to higher education should also be analysed among recent graduates and those who graduated earlier, although our database, regrettably, is not suitable for this. In addition, further qualitative research could be conducted to understand better whether there are other mechanisms besides human capital theory and Bourdieu's capital conversion model, which also explain the above findings.

Ethics: The study procedures were carried out in accordance with the Declaration of Helsinki. The Institutional Review Board of the Institute of Educational and Cultural Sciences (University of Debrecen) approved the study.

Funding sources: The data was realised in the framework of SZAKTÁRNET project (TÁMOP4.1.2.B.2-13/1-2013-0009).

Authors' contribution: All authors take responsibility for the integrity of the data and the accuracy of the data analysis. 
Conflict of interest: The authors declare no conflict of interest.

\section{ACKNOWLEDGEMENTS}

No additional acknowledgements.

\section{ABOUT THE AUTHORS}

Hajnalka Fényes PhD Habil. graduated as economist-sociologist in 1991 at Budapest, had her PhD degree in Sociology in 2001, and made her habilitation in Education science in 2010. She is an Associate Professor at the University of Debrecen at the Department of Sociology and Social Policy, educator and supervisor in the Doctoral School of Human Sciences (University of Debrecen). She participated in the 6biggest research of CHERD (Regional University Research, TERD, HERD, Campus-lét, IESA and now in a project dealing with dropout of students). Her research fields are the social mobility of HE students, the differences between males and females in the whole education system and the volunteering of students and she is also interested in quantitative methodology of sociology as well (multilevel analyses, contextual analysis).

Márta Mohácsi earned her PhD degree in regional studies in 2008. Her dissertation examined the relationship between education and the labour market. Alongside her experience of ten years in higher education as a Researcher and Lecturer, she has taken part in several further training programmes. Her research focus is management. She is Member of the editorial board for Crosssections - Social Science Journal.

\section{REFERENCES}

Becker, G. S. (1994). Human capital: A theoretical and empirical analysis with special reference to education. Chicago: University of Chicago Press.

Bocsi, V. (2015). A felsöoktatás értékmetszetei. [The value segments of higher education.]. Budapest: Új Mandátum Kiadó.

Bourdieu, P. (1986). The forms of capital. In J. G. Richardson (Ed.), Handbook of theory and research for the sociology of education (pp. 241-258). New York: Greenwood Press.

Christofides, L. N., Hoy, M., \& Yang, L. (2006). The determinants of university participation. http://ideas. repec.org/p/gue/guelph/2006-8.htm (Downloaded 11-01-2020).

Csillag, M., Scharle, Á., Molnár, T., \& Tóth, E. (2018). Fiatalok a munkaerőpiacon és az iskolában változások 2002 és 2018 között. [Young people in the labour market and education - changes between 2002 and 2018.]. In M. Csillag, Z. Hermann, \& Á. Scharle (Eds.), Közelkép. Fiatalok az iskolában és a munkaeröpiacon. [Close-up. Young people in education and the labour market] (pp. 37-47). https:// www.mtakti.hu/wp-content/uploads/2019/12/mt_2018_hun_33-150.pdf (downloaded 11-01-2020).

Engler, Á. (2012). Mothers as part-time students in higher education. In E. Juhász (Ed.), Education in transition (pp. 42-52). Dubnica nad Váhom, Szlovákia: Dubnický technologický inštitút v Dubnici nad Váhom. 
Engler, Á. (2013). Students with small children in higher education. Journal of Social Research and Policy, $4(1), 109-120$.

Fényes, H. (2010). A nemi sajátosságok különbségének vizsgálata az oktatásban. A nők hátrányainak felszámolódása? [Gender differences in education. Elimination of female disadvantages?]. Debrecen: Debreceni Egyetemi Kiadó.

Galasi, P. (2005). Labour market success of higher-education graduates. In K. Fazekas, \& J. Varga (Eds.), The Hungarian labour market, 2005: Review and analysis (pp. 93-100). Budapest: Hungarian Employment Foundation, Institute of Economics HAS.

Galasi, P. (2007). Earnings of higher-education graduates. In K. Fazekas, \& G. Kézdi (Eds.), The Hungarian labour market, 2007: Review and analysis (pp. 104-122). Budapest: Hungarian Employment Foundation, Institute of Economics HAS.

Kertesi, G., \& Köllö, J. (2007). Graduate earnings in 1992-2005. In K. Fazekas, \& G. Kézdi (Eds.), The Hungarian labour market, 2007: Review and analysis (pp. 78-85). Budapest: Hungarian Employment Foundation, Institute of Economics HAS.

Lepper, M. R. (1988). Motivational considerations in the study of instruction. Cognition and Instruction, 5(4), 289-309.

Mincer, J. (1958). Investment in human capital and personal income distribution. The Journal of Political Economy, 66, 281-302.

Pires, A. L. (2009). Higher education and adult motivation towards lifelong learning. An empirical analysis of university post-graduates perspectives. European Journal of Vocational Training, 46(1), 129-150.

Pusztai, G. (2014). The effects of institutional social capital on students' success in higher education. Hungarian Educational Research Journal (HERJ), 3, 1-13.

Pusztai, G. (2015). Pathways to success in higher education: Rethinking the social capital theory in the light of institutional diversity. Frankfurt am Main, Peter Lang Verlag.

Pusztai, G. (2018). The role of intergenerational social capital in diminishing student attrition. Journal of Adult Learning Knowledge and Innovation, 2(2), 1-7.

Samuelson P. A., \& Nordhaus, W. D. (2010). Economics. New York: McGraw-Hill Irwin.

Schultz, T. W. (1971). Investment in human capital; the role of education and of research. New York: The Free Press.

Thompson, M. N., \& Subich, L. M. (2006). The relation of social status to the career decision-making process. Journal of Vocational Behavior, 69(2), 289-301.

Veroszta, Z. (2014). Students' income-related motivations and expectations. International Journal of Social Sciences, 3(3), 165-184.

Open Access statement. This is an open-access article distributed under the terms of the Creative Commons Attribution 4.0 International License (https://creativecommons.org/licenses/by/4.0/), which permits unrestricted use, distribution, and reproduction in any medium, provided the original author and source are credited, a link to the CC License is provided, and changes - if any - are indicated. (SID_1) 